\title{
Purification and characterization of $\beta$ - secretase inhibitory peptide from sea hare (Aplysia kurodai) by enzymatic hydrolysis
}

\author{
Jung Kwon Lee, Sung Rae Kim and Hee-Guk Byun * (1)
}

\begin{abstract}
Amyloid plaque, also called senile plaque, the product of aggregation of $\beta$-amyloid peptides $(A \beta)$, is observed in brains of the patients with Alzheimer's disease (AD) and is one of the key factors in etiology of the disease. In this study, hydrolysates obtained from the sea hare (Aplysia kurodai) were investigated for $\beta$-secretase inhibitory peptide. The sea hare's muscle protein was hydrolyzed using six enzymes in a batch reactor. Trypsin hydrolysate had highest $\beta$-secretase inhibitory activity compared to the other hydrolysates. $\beta$-secretase inhibitory peptide was separated using Sephadex G-25 column chromatography and high-performance liquid chromatography on a C18 column. $\beta$-secretase inhibitory peptide was identified as eight amino acid residues of Val-Ala-Ala-Leu-Met-Leu-Phe-Asn by $\mathrm{N}$-terminal amino acid sequence analysis. $I_{50}$ value of purified $\beta$-secretase inhibitory peptide was $74.25 \mu \mathrm{M}$, and Lineweaver-Burk plots suggested that the peptide purified from sea hare muscle protein acts as a competitive inhibitor against $\beta$-secretase. Results of this study suggest that peptides derived from sea hare muscle may be beneficial as anti-dementia compounds in functional foods or as pharmaceuticals.
\end{abstract}

Keywords: $\beta$-secretase inhibitory activity, Sea hare muscle, Peptide, Purification, Alzheimer's disease

\section{Background}

Rapid economic development achieved in the elderly population increases due to the aging society. However, welfare of the elderly is extremely lacking. As the elderly population grows, the problem is an increase in patients with Alzheimer's disease (AD). AD is one of the most common senile dementia in the elderly. Symptoms of the disease include memory loss, confusion, impaired judgment, personality changes, disorientation, and loss of language skills. The ultimate cause of the disease is unknown. Probably, there is no single cause, but several factors that impact each person differently. In the late stage of the disease, AD brains include shrinkage of the gyri, widening of the sulci, and enlargement of ventricles with the two major microscopical lesions that are extracellular amyloid plaques and intracellular neurofibrillary tangles (Silvestrelli et al. 2006). Much of AD research has been focused on the amyloid cascade hypothesis that states that $\beta$-amyloid peptide $(A \beta)$, a proteolytic

* Correspondence: hgbyun@gwnu.ac.kr

Department of Marine Biotechnology, Gangneung-Wonju National University, Gangneung 25457, Republic of Korea derivative of the large trans-membrane protein amyloid precursor protein (APP), plays an early and crucial role in all cases of AD (Silvestrelli et al. 2006). The two necessary proteolytic cleavage events, one at the $\mathrm{N}$-terminus by an enzyme termed $\beta$-secretase and one at the $\mathrm{C}$-terminus by an enzyme termed $\gamma$-secretase, have attracted attention. This is understandable because $A \beta$ formation is the initial step in the hypothetical amyloid cascade (Hardy and Allsop 1991). Consequently, blocking production of $A \beta$ by specific inhibition of the $\beta-, \gamma-$ secretase required for $A \beta$ generation is a major focus of research in AD therapy (Citron 2002).

$\beta$-secretase is an aspartic protease known as BACE1 (the $\beta$-site APP-cleaving enzyme). This enzyme cleaves an easily accessible site at the luminal side of $\beta$-APP, and its activity is the rate-limiting step in $A \beta$ peptide production in vivo (Vassar et al. 1999). Excessive levels of $A \beta$ in the brain are closely related to $\mathrm{AD}$ pathogenesis, and thus, much research has been focused on developing drugs that can inhibit $\beta$-secretase and thereby reduce $A \beta$ levels, for therapeutic treatment of AD (Citron 2002). For the $\beta$-secretase inhibitor many groups have focused 
on identification of inhibitors using high-throughput screening of compound collections and natural product extracts. The peptidic $\beta$-secretase inhibitor, OM99-1 and other aspartic protease inhibitors (Dorrel 2000), OM992 , an 8-residue transition state inhibitor (Ghosh et al. 2000), and OM00-3, a more potent 8-residue transition state inhibitor (Turner et al. 2001). Non-peptidomimetic derivatives, such as analogues based on the phenylpiperazine scaffold with various heterocyclic moieties, have been synthesized to optimize BACE1 inhibition (Garino et al. 2006). Recently, small-sized synthetic inhibitors containing a tetrazole ring and acidic heterocycle bioisosteres such as KMI-570, KMI-684, KMI-420, and KMI-429 were synthesized (Kimura et al. 2006).

Sea hare (Aplysia kurodai) is a typical herbivorous gastropod feeding mainly on Laminariales and Fucales. The sea hare grazes seaweed fronds with gut teeth and digests them in stomach by using many kinds of digestive enzymes (Kumagai and Ojima 2010). Several studies have examined bioactivities of the sea hare, such as antioxidant and antimicrobial (Shin 2010), anti-cancer (Kim 2008), immune regulating (Park et al. 2011). Enzymatic hydrolysate revealed several advantages when added to foods, such as improving water-binding ability, heat stability of myofibrillar protein, emulsifying stability, solubility of protein, and nutritional quality of foods. Enzymatic hydrolysis has become a valuable tool for modifying functionality of proteins (Korhonen et al. 1998). Bioactive peptides usually contain 3-20 amino acid residues per molecule and are inactive within the sequence of the parent protein molecule. Bioactive peptides can be liberated by gastrointestinal digestion through proteolytic enzymes or during the fermentation process (Korhonen and Pihlanto 2006). The purpose of this study was to isolate and characterize $\beta$-secretase inhibitory peptide purified from sea hare muscle and to elucidate the active component of the peptide and its mode of inhibition on $\beta$-secretase.

\section{Methods}

\section{Materials}

Bones and viscera were removed from the sea hare and separated muscle was stored at $-80{ }^{\circ} \mathrm{C}$ until used. Various commercial enzymes, such as $\alpha$-chymotrypsin (from bovine pancreas), papain (from papaya latex), pepsin (from porcine gastric mucosa), and trypsin (from porcine pancreas) were purchased from Sigma Chemical CO. (St. Louis, MO). Alcalase (from Bacillus licheniformis) and Neutrase (Bacillus amyloliquefaciens) were purchased from Novo Co. (Novo Nordisk, Bagsvaerd, Denmark). $\beta$-secretase (from human) and MCA-EVKMDARFK(DNP)- $\mathrm{NH}_{2}$ ( $\beta$-secretase substrate I) was purchased from Sigma Chemical CO. (St. Louis, MO, USA). All other reagents used in this study were reagent grade chemicals.

\section{Analysis of approximate compositions}

Crude protein content was determined by the Kjeldahl method using an Auto Kjeldahl system (Buchi B-324/ 435/412, Switzerland). Crude lipid content was determined by the ether extraction method. Moisture content was determined by oven drying at $105{ }^{\circ} \mathrm{C}$ for $24 \mathrm{~h}$. Ash content was determined by a muffler furnace at $550{ }^{\circ} \mathrm{C}$ for $4 \mathrm{~h}$ (AOAC 2000). Amino acids were analyzed using an automatic analyzer (Hitachi Model 835-50, Japan) with a C18 column $(5 \mu \mathrm{m}, 4.6 \times 250 \mathrm{~mm}$, Watchers, MA, USA). The reaction was conducted at $38{ }^{\circ} \mathrm{C}$, with the detection wavelength at $254 \mathrm{~nm}$ and a flow rate of $1.0 \mathrm{~mL} / \mathrm{min}$. All chemical analyses (from each tank) were conducted in triplicate.

\section{Preparation of sea hare muscle protein hydrolysates}

To produce $\beta$-secretase inhibitory peptide from sea hare muscle, enzymatic hydrolysis was conducted using six different enzymes: Alcalase, $\alpha$-chymotrypsin, Neutrase, papain, pepsin, and trypsin under optimal conditions for $\mathrm{pH}$, temperature, and buffer (Table 1). At enzyme/substrate ratio of $1 / 100(w / w)$. The sample mixture was incubated for $6 \mathrm{~h}$ at each optimal temperature with shaking and then heated in a boiling water bath for $5 \mathrm{~min}$ to inactivate the enzyme. After the reaction, reactant was conducted by glass filter and lyophilized hydrolysates were stored at $80{ }^{\circ} \mathrm{C}$ until use.

\section{Measurement of $\beta$-secretase inhibitory activity}

$\beta$-secretase inhibitory activity was measured following Johnston's method (Johnston et al. 2008) using a commercially available fluorogenic substrate, MCA-EVKMDAEFK(DNP)- $\mathrm{NH}_{2}$ (Sigma-Aldrich, MO, USA). This substrate corresponds to the wild-type APP sequence, derivatized at its N-terminus with a fluorescent 7-methoxycoumarin4-yl acetyl (MCA) group, and on its C-terminal lysine residue with a 2,4-dinitrophenyl (DNP) group. In the intact peptide, the fluorescence of the MCA group is abolished by internal quenching from the DNP group. Upon cleavage by $\beta$-secretase (Sigma-Aldrich, MO, USA), MCA fluorescence can be detected. Assays were conducted in 96-well black plates using the Infinite 200 Pro multimode microplate reader (Tecan, Männedorf, Switzerland). $\beta$-secretase

Table 1 Optimum hydrolysis conditions of sea hare muscle hydrolysates obtained by various enzymes

\begin{tabular}{llll}
\hline Enzyme & Buffer & $\mathrm{pH}$ & Temperature $\left({ }^{\circ} \mathrm{C}\right)$ \\
\hline Alcalase & $50 \mathrm{mM} \mathrm{Na} \mathrm{HPO}_{4}-\mathrm{NaH}_{2} \mathrm{PO}_{4}$ & 7.0 & 50 \\
a-chymotrypsin & $50 \mathrm{mM} \mathrm{Na}_{2} \mathrm{HPO}_{4}-\mathrm{NaH}_{2} \mathrm{PO}_{4}$ & 7.0 & 37 \\
Neutrase & $50 \mathrm{mM} \mathrm{Na}_{2} \mathrm{HPO}_{4}-\mathrm{NaH}_{2} \mathrm{PO}_{4}$ & 7.0 & 50 \\
Papain & $50 \mathrm{mM} \mathrm{Na} \mathrm{HPO}_{4}-\mathrm{NaH}_{2} \mathrm{PO}_{4}$ & 7.0 & 37 \\
Pepsin & $20 \mathrm{mM} \mathrm{Glycine}-\mathrm{HCl}$ & 2.0 & 37 \\
Trypsin & $50 \mathrm{mM} \mathrm{Na} \mathrm{HPO}_{4}-\mathrm{NaH}_{2} \mathrm{PO}_{4}$ & 7.0 & 37 \\
\hline
\end{tabular}


and $\beta$-secretase substrate were incubated in assay buffer (50 mM sodium acetate, $\mathrm{pH} 4.5$ ) in a final volume of $100 \mu \mathrm{L}$. The progress of hydrolysis of $\beta$-secretase substrate I was followed at $37{ }^{\circ} \mathrm{C}$ for $30 \mathrm{~min}$ by measuring the accompanying increase in fluorescence. Readings (excitation $320 \mathrm{~nm}$, emission $450 \mathrm{~nm}$ ) were taken every $60 \mathrm{~s}$. The inhibition (\%) was then obtained by the following equation:

$$
\text { Inhibition }(\%)=[1-\{(\mathrm{S}-\mathrm{S} 0) /(\mathrm{C}-\mathrm{C} 0)\}] \times 100
$$

where $C$ is the fluorescence of a control (enzyme, assay buffer, and substrate) after $60 \mathrm{~min}$ of incubation, $C O$ is the fluorescence of the control at zero time, $S$ is the fluorescence of the test sample (enzyme, sample solution, and substrate) after $60 \mathrm{~min}$ of incubation, and $S O$ is the fluorescence of the test sample at zero time. All data are expressed as the means of triplicate experiments. $\mathrm{IC}_{50}$ value is the concentration of sea hare muscle or peptide yielding $50 \%$ inhibition of $\beta$-secretase activity.

\section{Purification of $\beta$-secretase inhibitory peptide}

The potent fraction as determined from $\beta$-secretase inhibitory activity assay was further purified by size exclusion chromatography on a Sephadex G-25 gel filtration column $(\varnothing 25 \times 750 \mathrm{~mm})$ equilibrated with distilled water. Separated fractions were monitored at $215 \mathrm{~nm}$, collected at a volume of $7.5 \mathrm{~mL}$, and measured for $\beta$-secretase inhibitory activity. Highest active fraction was injected into a preparative reverse phase HPLC (RP-HPLC) column (Grom-Sil 120 ODS-5ST, ø $10.0 \times 250$ mm, $5 \mu \mathrm{m}$, Grom $^{\mathrm{T \mu}}$, Germany) and was separated using linear gradient of acetonitrile $(0-45 \% \quad v / v)$ containing $0.1 \%$ trifluoroacetic acid (TFA) on an RP-HPLC system (Agilent Technologies, USA). Elution peaks were monitored at $215 \mathrm{~nm}$ on diode array detector (DAD). The potent peak was finally purified as a single peptide on a RP-HPLC analytical C18 column (ø $4.6 \times 250 \mathrm{~mm}, 5 \mu \mathrm{m}$, Waters, Milford, MA, USA) using a linear gradient of acetonitrile $(0-25 \%, v / v)$ in $0.1 \%$ TFA. Elution peaks were monitored at $215 \mathrm{~nm}$ on DAD.

\section{Amino acid sequencing of purified peptide}

To identify molecular weight and amino acid sequence of the purified peptide, all MS/MS experiments were conducted by nano-electrospray ionization (ESI) on a quadrupole time-of-flight (Q-TOF) tandem mass spectrometer (AB Sciex Instruments, CA 94404, USA). Peptide solution was desalted using Capcell Pak C18 UG120 V (ø $4.6 \times$ $250 \mathrm{~mm}, 5 \mu \mathrm{m}$, Shiseido, Tokyo, Japan). Purified peptide dissolved in methanol/water $(1: 1, v / v)$ was infused into the ESI source and molecular weight was determined by doubly charged $(\mathrm{M}+2 \mathrm{H})^{2+}$ state in the mass spectrum. Following molecular weight determination, the peptide was automatically selected for fragmentation, and sequence information was obtained by tandem MS analysis.
Determination of the mode of inhibition of $\beta$-secretase inhibitory peptide

To investigate the mode of inhibition on $\beta$-secretase inhibitory peptide, purified inhibitor was added to each reaction mixture. Inhibition constants $(K i)$ of $\beta$-secretase inhibitors were calculated using Dixon plots. For determination of kinetics of purified peptide, inhibition rates were measured at three concentrations of the substrate (5, 10, 20, and $40 \mathrm{nM})$. For Dixon plots, data were obtained as mean values of $1 / \mathrm{V}$ (reaction velocity), inverse of the increase in fluorescence intensity per minute (min/relative fluorescence unit, RFU) of three independent tests with different concentrations (25, 50, and $100 \mu \mathrm{M})$ of inhibitor. The assay was conducted in the presence of purified inhibitor.

\section{Statistical analysis}

Data were subjected to one-way analysis of variance (ANOVA) to test the $\beta$-secretase inhibitory activity of synthesized peptides. When significant differences $(p<0.05)$ were found in one-way ANOVA, Duncan's (Duncan 1955) multiple range test was used to rank groups. All references to significant differences indicate $p<0.05$. All statistical analyses were conducted using SPSS program version 14.0 for Windows (SPSS Michigan Avenue, Chicago, IL, USA). Data are presented as Mean \pm SE of three replications.

\section{Results and discussion}

\section{Approximate compositions of sea hare muscle}

Approximate compositions of sea hare muscle are presented in Table 2. Crude protein content was $51.40 \%$, while lipid, moisture, carbohydrate, and ash contents were $18.20,5.50,5.00$, and $20.00 \%$, respectively. Choi and Han (1985) reported approximate compositions of sea hare were $6.33 \%$ protein, $1.60 \%$ lipid, $2.47 \%$ ash. In comparison with our study, high protein content suggests the extraction process using enzymatic hydrolysis was effective. Because sea hare muscle has a high protein content, they are converted to various physiological peptide materials through enzymatic hydrolysis reactions. Amino acid compositions of sea hare muscle were as follows: glutamic acid (16.45\%), glycine (11.68\%), aspartic acid (10.74\%), alanine (8.87\%), and leucine (8.32\%) (Table 3).

Table 2 Proximate composition of sea hare muscle

\begin{tabular}{lll}
\hline & Contents (\%) \\
\cline { 2 - 3 } & Before lyophilized & After lyophilized \\
\hline Moisture & 90.1 & 5.5 \\
Crude protein & 5.8 & 51.4 \\
Crude lipid & 1.5 & 18.2 \\
Carbohydrate & 0.5 & 5.0 \\
Ash & 2.6 & 20.0 \\
\hline
\end{tabular}


Table 3 Amino acid compositions of sea hare muscle

\begin{tabular}{ll}
\hline Amino acids & Contents (\%) \\
\hline Asp & 10.74 \\
Thr & 5.44 \\
Ser & 7.44 \\
Glu & 16.45 \\
Gly & 11.68 \\
Ala & 8.87 \\
Cys & 0.28 \\
Val & 4.68 \\
Met & 1.75 \\
Ile & 3.92 \\
Leu & 8.32 \\
Tyr & 2.06 \\
Phe & 2.67 \\
Lys & 6.72 \\
His & 1.39 \\
Arg & 6.37 \\
Hypro & 0.18 \\
Pro & 1.05 \\
Total & 100.00 \\
\hline
\end{tabular}

$\beta$-secretase inhibitory activity of enzymatic hydrolysate of sea hare muscle

Many studies reported that $\beta$-secretase cleavage is reported to occur in acidic compartments such as the endosomal system and the trans-Golgi network, although significant amounts of the glycoprotein are also present in the endoplasmic reticulum and on the cell surface [Cook et al. 1997, Huse et al. 2002]. $\beta$-secretase shows maximum activity at $\mathrm{pH} 4.0-4.5$, and an acidic $\mathrm{pH}$ is usually employed for in-vitro assays. $\beta$-secretase exerts its enzymatic activity via a general acid-based mechanism common to aspartyl proteases. To do so, we measure $\beta$-secretase inhibitory activity of enzymatic hydrolysates under $\mathrm{pH} 4.5$ condition. Peptides from six hydrolysates were evaluated for their $\beta$-secretase inhibitory activities by $\mathrm{IC}_{50}$ value $(\mathrm{mg} / \mathrm{mL})$. As shown in Fig. 1 , $\beta$-secretase inhibitory activity of extracts produced by various enzymes, trypsin, $\alpha$-chymotrypsin, and Neutrase were $0.34,0.44$, and $0.51 \mathrm{mg} / \mathrm{mL}$, respectively. Among various enzymatic hydrolysates, trypsin hydrolysate exhibited highest $\beta$-secretase inhibitory activity. Trypsin is a serine protease that plays a key role in activation of pancreatic enzymes involved in digestion. It is released from zymogen granules stored in pancreatic acinar cells and becomes activated by enterokinase upon secretion (Stroud et al. 1997). Trypsin cleaves peptide bonds at the carboxyl-terminal end of lysine and arginine residues, and can activate zymogen. Once activated, trypsin activates

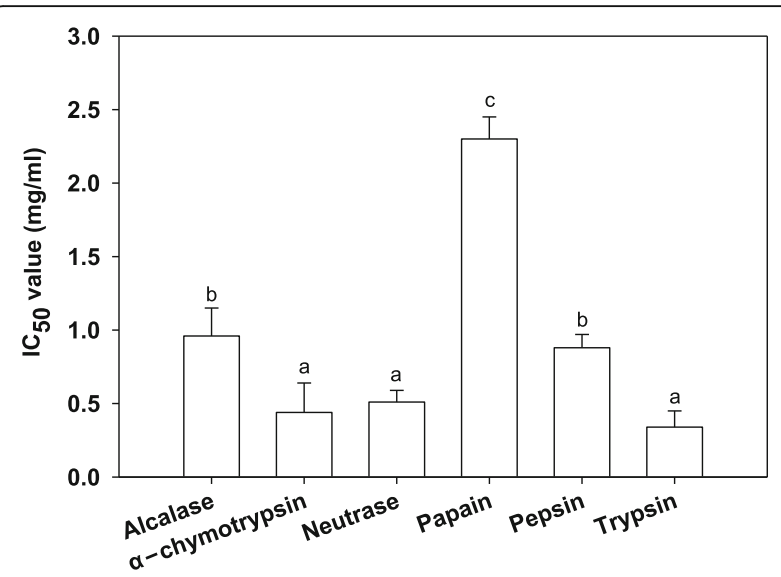

Fig. $1 \mid C_{50}$ value of $\beta$-secretase inhibitory activity of sea hare muscle hydrolysates by enzymatic hydrolysis. Statistical significance was determined by ANOVA (Duncan's test, mean $\pm \mathrm{SD} ; n=3$ ). ANOVA test results are shown as letters above columns. Means not sharing the same letter are significantly different

other digestive proteases that have been synthesized as zymogens and it can digest almost any protein that has basic amino acids as part of its sequence (Neurath and Walsh 1976). Enzymatic hydrolysis is one of the primary approaches for effective release of bioactive peptides from protein sources and is widely used to improve and upgrade functional and nutritional properties of proteins (Je et al. 2005).

\section{Purification of $\beta$-secretase inhibitory peptide}

To identify the $\beta$-secretase inhibitory peptides derived from trypsin hydrolysate of sea hare muscle that had highest $\beta$-secretase inhibitory activity, peptides were separated by Sephadex G-25 column chromatography into four fractions (F1-F4) (Fig. 2I). Sephadex G-25 column chromatography separates according to molecular size, where primary fractions contain large molecular-size peptides, and secondary fractions contain small molecular-size peptides. It has been applied for group separation of protein hydrolysates and biological extracts. We found that fraction F2 possessed strong $\beta$-secretase inhibitory activity at $0.10 \mathrm{mg} / \mathrm{mL}$ (Fig. 2I).

The lyophilized F2 fraction from Sephadex G-25 chromatography was further separated into five fractions (A -E) by RP-HPLC on a ODS column with a linear gradient of acetonitrile (0-45\%) (Fig. 2II). Among the separated fractions, fraction $C$ revealed the highest $\beta$-secretase inhibitory activity with an $\mathrm{IC}_{50}$ value of $89.43 \mu \mathrm{g} / \mathrm{mL}$, fraction $\mathrm{C}$ was further separated by RP-HPLC using the C18 analytical column. Then, we purified two fractions $(\mathrm{C}-1$ and $\mathrm{C}-2$ ) from trypsin hydrolysate (Fig. $2 \mathrm{III}) . \mathrm{IC}_{50}$ value for the $\beta$-secretase inhibitory activity of fractions $\mathrm{C}-1$ and $\mathrm{C}-2$ were 65.12 and $111.93 \mu \mathrm{g} / \mathrm{mL}$, respectively. Fraction $\mathrm{C}-1$, with strongest $\beta$-secretase inhibitory activity, was 
(I)
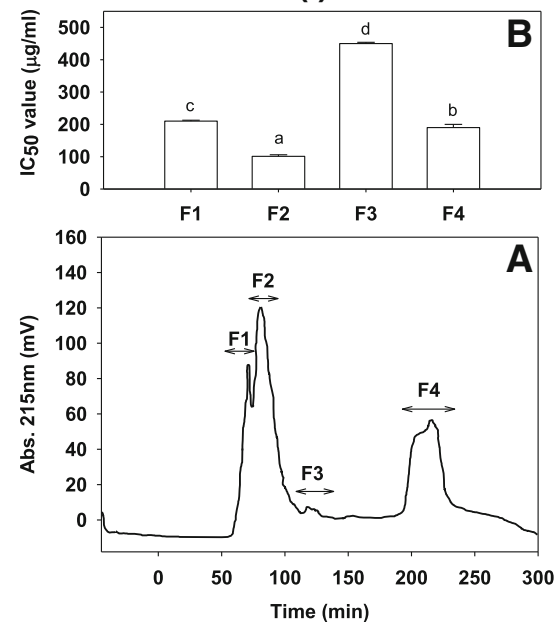

(III)
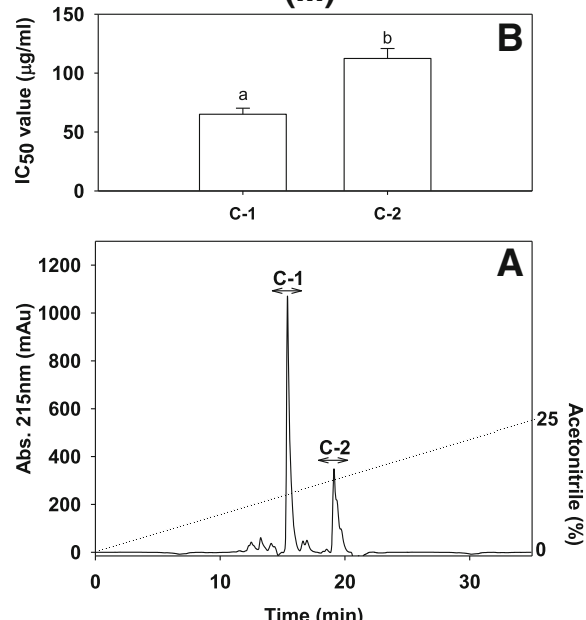

(II)
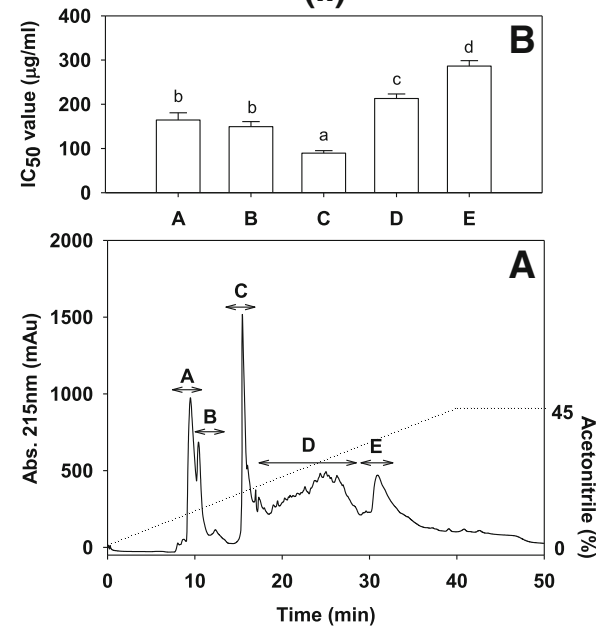

(IV)
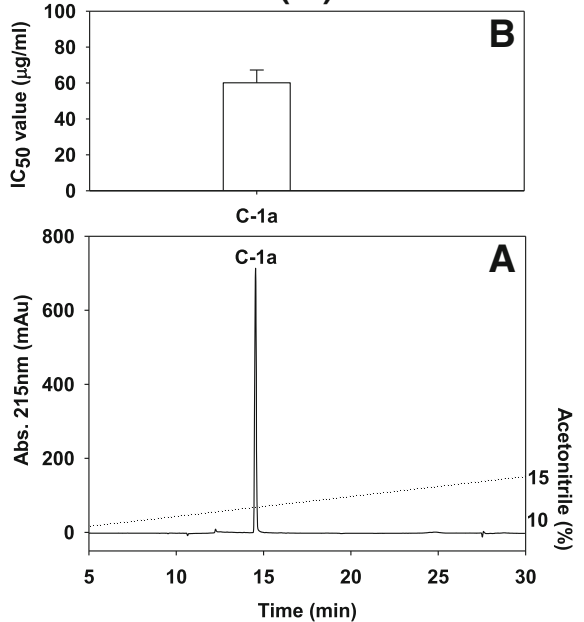

Fig. 2 The steps for purification of $\beta$-secretase inhibitory peptide from sea hare muscle hydrolysate. (I) Sephadex G-25 Gel filtration chromatogram of hydrolysates. (II, III, IV) Reverse phase-HPLC chromatograms of the potent $\beta$-secretase inhibitory fractions from the previous steps. The lower panels (a) of each pair show the chromatography results of the separated fractions while the top panels (b) of each pair represent the $\beta$-secretase inhibitory activity of the separated fractions in terms of their $I_{50}$ values expressed in $\mu \mathrm{g} / \mathrm{ml}$. Statistical significance was determined by ANOVA (Duncan's test, mean $\pm \mathrm{SD} ; n=3$ ). ANOVA test results are shown as letters above columns. Means not sharing the same letter are significantly different

purified further using RP-HPLC on the C18 analytical column a linear gradient of acetonitrile (10-15\%) for $30 \mathrm{~min}$ at a flow rate of $1.0 \mathrm{ml} / \mathrm{min}$ (Fig. $2 \mathrm{IV}$ ). $\mathrm{IC}_{50}$ value of purified peptide was $60.12 \mu \mathrm{g} / \mathrm{mL}$, 5.66-fold compared to the typsin hydrolysate $(0.34 \mathrm{mg} / \mathrm{mL})$ using the three-step purification procedure (Table 4).

\section{Amino acid sequence of purified $\beta$-secretase inhibitory peptide}

Amino acid sequences of purified $\beta$-secretase inhibitory peptide were identified using MS/MS and shown to be Gln-Gly-Thr-Arg-Pro-Leu-Arg-Gly-Pro-Glu-Phe-Leu with $\mathrm{IC}_{50}$ value and molecular weight of $74.25 \mu \mathrm{M}$ and 877 Da (Fig. 3). Amino acid composition, sequence, and length may be critical characteristics determining $\beta$-secretase inhibitory activity of peptides. Various $\beta$-secretase inhibitors, many studies have focused on identification of inhibitors using high-throughput

Table 4 Purification of $\beta$-secretase inhibitory peptide from sea hare muscle hydrolysate obtained by trypsin treatment

\begin{tabular}{lll}
\hline Purification step & $\mathrm{IC}_{50}$ value $(\mu \mathrm{g} / \mathrm{mL})$ & Purification fold* \\
\hline Trypsin hydrolysate & $340.31 \pm 0.10$ & 1.00 \\
Sephadex gel filtration (F2) & $101.11 \pm 0.03$ & 3.37 \\
RP-HPLC (C) & $89.43 \pm 0.03$ & 3.81 \\
Purified peptide (C-1) & $60.12 \pm 0.05$ & 5.66
\end{tabular}

*Relative value of reciprocal of $\beta$-secretase inhibitory activity by $\mathrm{IC}_{50}$ 


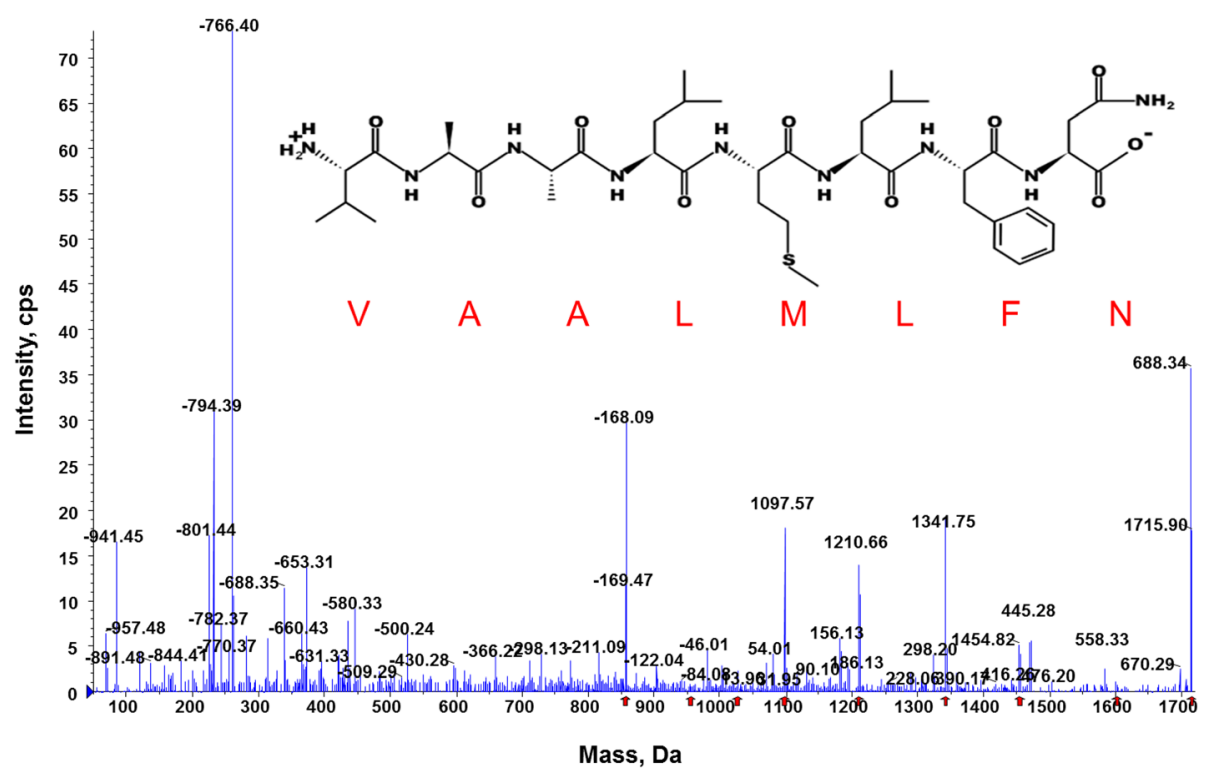

Fig. 3 Identification of molecular weight and amino acid sequence of the purified peptide from sea hare muscle hydrolysate. MS/MS experiments were performed on a Q-TOF tandem mass spectrometer equipped with a nano-ESI source. All MS/MS spectra were acquired using a Thermo Finnigan (San Jose, CA, USA) LTQ mass spectrometer. Each full MS (m/z range, 100-2000) scan was followed by three MS/MS scans of the most abundant precursor ions in the MS spectrum with dynamic exclusion enabled. Sequencing of the purified peptides was acquired over the m/z range 100-1800 and sequenced by using de novo sequencing program

screening of compound collections and natural product extracts. Substrate-based inhibitors have been designed using knowledge of the specificity of the $\beta$-secretase catalytic mechanism. The peptidic hydroxyethylenebased compound OM99-2 was one of the first and most active compounds [Hong et al. 2005]; with low nanomolar activity, these peptidic $\beta$-secretase (aspartic protease memapsin-2) inhibitor, OM 99-1 and OM00-3 and other aspartic protease inhibitors have been developed (Turner et al. 2001).

According to the report by $\beta$-secretase inhibitory peptides isolated from marine organisms, Lee et al. (2015) found the amino acid sequence of a purified $\beta$-secretase inhibitor peptide from skate skin hydrolysate was Gln-Gly-Thr-Arg-ProLeu-Arg-Gly-Pro-Glu-Phe-Leu with N-terminal sequence analysis. Molecular weight of the purified $\beta$-secretase inhibitor was estimated at $1391 \mathrm{Da}$ by LC-MS, and its $\beta$-secretase inhibitory activity $\mathrm{IC}_{50}$ value was $24.26 \mu \mathrm{M}$. Li et al. (2016) determined an $\mathrm{IC}_{50}$ value of $92.70 \mu \mathrm{M}$ from shrimp waste hydrolysate (Asp-Val-Leu-Phe-His), but the $\beta$-secretase inhibitory activity of the purified peptide from sea hare muscle hydrolysate was greater than that of shrimp waste hydrolysate. Thus, sequencing and structure of peptides may be related to $\beta$-secretase inhibitory activity. Purified $\beta$-secretase inhibitory peptide acted competitively with a substrate according to Lineweaver-Burk plots (Fig. 4). Competitive inhibitor has affinity for the active site of an enzyme where the substrate binds. This leads the substrate and the inhibitor to compete for access to the enzyme's active site. Competitive inhibitors often mimic the structure of natural substrates. Inversely, sufficiently high concentrations of the natural substrate can outcompete the inhibitor and reduce its effects (Menting and Claassen 2014).

The $\beta$-secretase active site is characterized by the presence of hydrophilic and small hydrophobic pockets and is enclosed by a flexible antiparallel $\beta$-hairpin which controls substrate access to the active site for the catalytic process [Lee et al. 2009, Hong et al. 2005, Congreve et al. 2007]. The regulation of $\beta$-secretase activity in the modulation of substrate affinity and catalytic properties is

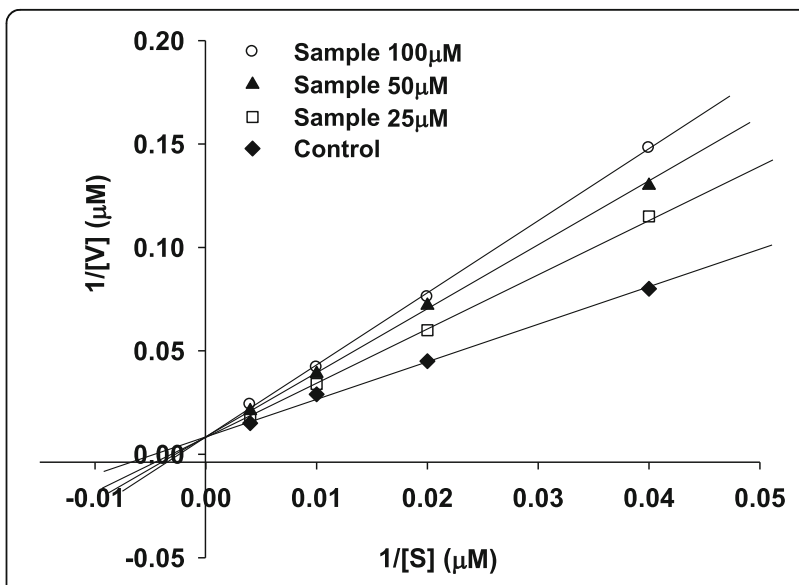

Fig. 4 Lineweaver-Burk plot of $\beta$-secretase inhibitory activity in the presence of the purified peptide 
caused by large-scale conformational changes between the active and the inactive forms. Detailed information on the subsite specificity of the $\beta$-secretase catalytic site was based on the crystal structure [Hong et al. 2005] and results from both substrate kinetics and the screening of a combinatorial inhibitor library [Turner et al. 2001]. The location and topology of the eight critical amino acids (P1-P4; P'1-P'4) proximal to the scissile bond were clearly defined and used to design better peptide substrates and inhibitors. Each subsite can accommodate multiple residues, but the $\mathrm{S} 1$ subsite is the most stringent in preferring residue Leu $>$ Phe $>$ Met $>$ Tyr, whereas the preferences of other subsites are as follows: Asp $>$ Asn $>$ Met for S2, Ile $>$ Val $>$ Leu for S3, and Glu $>$ Gln $>$ Asp for S4. In our $\beta$-secretase inhibitory activity assay used Swedish mutation substrate. An optimized peptide comprising the eight most favored residues and the Swedish mutation (Glu-Ile-Asp-Leu-Met-Val-Leu-Asp) was found that leucine is likely to be the key residue for $\beta$-secretase inhibition. Especially, leucine plays a crucial role in the Swedish mutant APP that has a mutation at the P2-P1 positions from Lys-Met to Asn-Leu. Generally, $\beta$-secretase has eight (P1-P4 and P1'-P4') residues that are critical in the catalytic domain, determined by its crystal structure. Inhibitory activities against $\beta$-secretase when the P2 position was changed to several other amino acids have been described (Hong et al. 2005). Also, the purified $\beta$-secretase inhibitory peptide characteristic that specific amino acid sequencing involved leucine might bind to P2 of active sites competitively and inhibit binding of $\beta$-secretase and its substrate.

\section{Conclusions}

In this study, we first purified novel $\beta$-secretase inhibitory peptide from enzymatic hydrolysate of sea hare muscle. Results revealed that purified peptide had significant inhibition of $\beta$-secretase activity with $\mathrm{IC}_{50}$ value of $74.25 \mu \mathrm{M}$ and a molecular weight of $877 \mathrm{Da}$. $\beta$-secretase inhibitors prevent production of new $A \beta$ plaques, but hypothetically do not influence already existing $A \beta$ peptides. Therefore, $\beta$-secretase inhibitors are potentially better at preventing $\mathrm{AD}$ instead of having therapeutic use. Results of this study suggest that the $\beta$-secretase inhibitory peptide from sea hare muscle protein has the potential health benefits for use in Alzheimer's diseases.

\footnotetext{
Abbreviations

AD: Alzheimer's disease; ANOVA: Analysis of variance; APP: Amyloid precursor protein; $A \beta$ : $\beta$-amyloid peptide; BACE1: The $\beta$-site APP-cleaving enzyme; DAD: diode array detector; DNP: 2,4-dinitrophenyl; ESI: Electrospray ionization; HIV: Human immunodeficiency virus; MCA: 7-methoxycoumarin-4-yl acetyl; Q-TOF: Quadrupole time-of-flight; RFU: Relative fluorescence unit; RP-HPLC: Reverse phase high performance liquid chromatography; TFA: Trifluoroacetic acid
}

\section{Acknowledgements}

This research was supported by Basic Science Research Program through the National Research Foundation of Korea (NRF) funded by the Ministry of Education.

\section{Funding}

The design of the study; collection, analysis, and interpretation of the data; and writing of the manuscript were funded by a grant from the Ministry of Education, Republic of Korea (2012R1A1A2008627).

\section{Availability of data and materials}

All datasets generated during and/or analyzed during the current study are available from the corresponding author on reasonable request.

\section{Authors' contributions}

HGB and LJK conceived and designed the study and helped to draft the manuscript and revised the manuscript. KSR prepared the samples and assisted with data collection. LJK performed the experiment, analyzed the data, and drafted the manuscript. All authors read and approved the final manuscript.

Ethics approval and consent to participate

Not applicable.

\section{Consent for publication}

Not applicable.

\section{Competing interests}

The authors declare that they have no competing interests.

\section{Publisher's Note}

Springer Nature remains neutral with regard to jurisdictional claims in published maps and institutional affiliations.

Received: 4 January 2018 Accepted: 13 February 2018 Published online: 17 May 2018

\section{References}

Association of Official Analytical Chemist (AOAC). Official Methods of Analysis. 17th ed. Washington: Association of Official Analytical Chemist; 2000.

Choi YJ, Han YS. Protein and amino acid compositions in echiurid and sea hare muscles. Korean Soc Fisheries Aquatic Sci. 1985;18:550-6.

Citron M. $\beta$-secretase as a target for the treatment of Alzheimer's disease. J Neurosci Res. 2002;70:373-9.

Congreve M, Aharony D, Albert J, Callaghan O, Campbell J, Carr RA, Chessari G, Cowan S, Edwards PD, Frederickson M, McMenamin R, Murray CW, Patel S, Wallis N. Application of fragment screening by X-ray crystallography to the discovery of aminopyridines as inhibitors of beta-secretase. J Med Chem. 2007;50:1124-32.

Cook DG, Forman MS, Sung JC, Leight S, Kolson DL, Iwatsubo T, Lee VM, Doms RW. Alzheimer's a beta (1-42) is generated in the endoplasmic reticulum/ intermediate compartment of NT2N cells. Nat Med. 1997;3:1021-3.

Dorrel S. Untangling Alzheimer's disease with $\beta$-secretase inhibitors. Drug Discov Today. 2000;5:316-7.

Duncan DB. Multiple range and multiple F-tests. Biometrics. 1955;11:1-12.

Garino C, Pietrancosta N, Laras Y, Moret V, Rolland A, Quelever G. BACE1 inhibitory activities of new substituted phenylpiperazine coupled to various heterocycles: chromene, coumarin and quinoline. Bioorg Med Chem Lett. 2006;16:1995-9.

Ghosh AK, Shin D, Koelsch G, Lin X, Ermolieff J, Tang J. Design of potent inhibitors for human brain memapsin 2 ( $\beta$-secretase). J Am Chem Soc. 2000; 122:3522-3.

Hardy J, Allsop D. Amyloid deposition as the central event in the aetiology of Alzheimer's disease. Trends Pharmacol Sci. 1991;12:383-8.

Hong L, He X, Huang X, Chang W, Tang J. Structural features of human memapsin 2 ( $\beta$-secretase) and their biological and pathological implications. Acta Biochim Biophys Sin. 2005;36:787-92.

Huse JT, Liu K, Pijak DS, Carlin D, Lee VM, Doms RW. Beta-secretase processing in the trans-Golgi network preferentially generates truncated amyloid species that accumulate in Alzheimer's disease brain. J Biol Chem. 2002;277:16278-84. 
Je JY, Park PJ, Byun HG, Jung WK, Kim SK. Angiotensin I converting enzyme (ACE) inhibitory peptide derived from the sauce of fermented blue mussel, Mytilus edulis. Bioresour Technol. 2005;96:1624-9.

Johnston JA, Liu WW, Coulson DTR, Todd S, Murphy S, Brennan S. Platelet $\beta$-secretase activity is increased in Alzheimer' disease. Neurobiol Aging. 2008;29:661-8.

Kim WS. The study on anticancer activity from sea hare (Aplysia kurodai) eggs. Unpublished doctoral dissertation. Jeju: Jeju National University; 2008.

Kimura T, Hamada Y, Stochaj M, Ikari H, Nagamine A, Abdel-Rahman H. Design and synthesis of potent $\beta$-secretase (BACE1) inhibitors with carboxylic acid bioisosteres. Bioorg Med Chem Lett. 2006;16:2380-6.

Korhonen $\mathrm{H}$, Pihlanto A. Bioactive peptides: production and functionality. Int Dairy J. 2006;16:945-60.

Korhonen M, Pihlanto-Leppäla A, Tupasela T. Impact of processing on bioactive proteins and peptides. Trends Food Sci Technol. 1998:9:307-19.

Kumagai Y, Ojima T. Isolation and characterization of two types of $\beta-1,3$ - glucanases from the common sea hare Aplysia kurodai. Comp Biochem Physiol B. 2010;155:138-44.

Lee JK, Li-Chan ECY, Byun HG. Characterization of $\beta$-secretase inhibitory peptide purified from skate skin protein hydrolysate. Eur Food Res Technol. 2015;240: 129-36.

Lee JY, Lee SA, Kim JK, Chae CB, Kim Y. Interaction models of substrate peptides and $\beta$-secretase studied by NMR spectroscopy and molecular dynamics simulation. Mol Cells. 2009;27;651-6.

Li-Chan ECY, Cheung IWY, Byun HG. Shrimp (Pandalopsis dispar) waste hydrolysate as a source of novel $\beta$-secretase inhibitors. Fish Aquat Sci. 2016; 19:11.

Menting KW, Claassen JA. $\beta$-secretase inhibitor; a promising novel therapeutic drug in Alzheimer's disease. Front Aging Neurosci. 2014;6:165.

Neurath $\mathrm{H}$, Walsh KA. Role of proteolytic enzymes in biological regulation. Proc Natl Acad Sci. 1976;73:3825-32.

Park SH, Choung SY, Choi YJ. Immune regulating effect of polysaccharide fraction from sea hare (Aplysia kurodai). J Korean soc. Food Sci Nutr. 2011;40:372-8.

Shin MO. The antioxidative and antimicrobial effect of internal organs of Aplysia kurodai fraction. J Korean Fisheries Aquatic Sci. 2010;18:550-6.

Silvestrelli G, Lanari A, Parnetti L, Tomassoni D, Amenta F. Treatment of Alzheimer's disease: from pharmacology to a better understanding of disease pathophysiology. Mech Ageing Dev. 2006;127:148-57.

Stroud RM, Kossiakoff AA, Chambers JL. Mechanisms of zymogen activation. Annu Rev Biophys Bioeng. 1997;6:177-93.

Turner RT, Koelsch G, Hong L, Castanheira P, Ermolieff J, Ghosh AK. Subsite specificity of memapsin 2 ( $\beta$-secretase): implications for inhibitor design. Biochemist. 2001;40:10001-6.

Vassar R, Bennett BD, Babu-Khan S, Kahn S, Mendiaz EA, Denis P. $\beta$-secretase cleavage of Alzheimer's amyloid precursor protein by the transmembrane aspartic protease BACE. Science. 1999;286:735-41.

\section{Submit your next manuscript to BioMed Central and we will help you at every step:}

- We accept pre-submission inquiries

- Our selector tool helps you to find the most relevant journal

- We provide round the clock customer support

- Convenient online submission

- Thorough peer review

- Inclusion in PubMed and all major indexing services

- Maximum visibility for your research

Submit your manuscript at www.biomedcentral.com/submit
Biomed Central 